\title{
Pengaruh Ukuran Partikel terhadap Karakteristik Riser Sleeve Sekam Padi Pada Aplikasi Pengecoran Baja
}

Dewi Idamayanti, Wiwik Purwadi, Hamim Al Gary

Politeknik Manufaktur Bandung, Jl. Kanayakan No. 21, Bandung

*Email : idamayanti79@gmail,com

(Diterima 24 Oktober 2019; Disetujui 30 Mei 2020; Dipublikasikan 16 September 2020)

\begin{abstract}
Abstrak
Sekam padi mempunyai potensi besar sebagai material eksotermik yang umum dimanfaatkan sebagai bahan briket karena menghasilkan nilai kalor yang cukup tinggi. Dalam bidang pengecoran baja, material eksotermik seperti sekam padi dapat dimanfaatkan sebagai riser sleeve untuk memperpanjang waktu pembekuan baja sekaligus mengatasi penyusutan baja. Ukuran partikel sekam padi yang diteliti adalah 40 mesh dan 60 mesh, dipisahkan dengan sieve shaker. Penentuan jumlah bahan pengikat diujicoba pada rentang $10-18 \%(b / b)$. Penggunaan bahan pengikat sesedikit mungkin karena mempengaruhi terhadap kinerja sebuah riser sleeve. Hasil pengujian kompresi menunjukan pengikat dengan kadar $11 \%$ sudah memenuhi standar minimal kekuatan kompresi $5 \mathrm{~kg} / \mathrm{cm}^{2}$. Selanjutnya, sekam padi yang berukuran 40 mesh maupun 60 mesh dibentuk dengan tipe $\mathrm{H}$-sleeve berbahan pengikat $11 \%$, dipadatkan melalui hand pressing dan dikeringkan pada $120^{\circ} \mathrm{C}$ selama 2 jam. Kinerja sleeve sekam padi sebagai riser diuji pada pengecoran baja karbon rendah melalui pengukuran laju solidifikasi baja dan modulus extension factor. Diperoleh bahwa sleeve sekam padi berukuran 40 mesh mampu menahan laju pembekuan baja 52 detik lebih lama dibandingkan sleeve sekam padi berukuran 60 mesh. Hal ini disebabkan porositas pada sleeve berukuran 40 mesh lebih tinggi sehingga memberikan efek insulasi lebih baik dari sleeve 60 mesh. Modulus extension factor untuk sleeve sekam padi berukuran 40 mesh dan 60 mesh adalah 1,9 dan 1,75. Kedua sleeve tersebut dapat diklasifikasikan sebagai exothermic sleeve menurut Indian Standar 15865 : 2009.
\end{abstract}

Kata kunci: exothermic sleeve, pengecoran baja, riser sleeve, sekam padi

\section{Latar Belakang}

Riser sleeve adalah sistem penambah (feeding aid) pada cetakan pasir untuk mensuplai cairan baja selama proses penyusutan [1,2]. Penggunaan riser sleeve umumnya digunakan untuk pengecoran baja karena mempunyai waktu pembekuan yang pendek [3]. Riser sleeve mempunyai kinerja yang lebih tinggi dari sand riser yang umum digunakan sebagai penambah pada cetakan pengecoran baja, dengan cara memperlambat penurunan suhu solidifikasi dan pembentukan skin layer pada cairan logam dalam riser [1]. Jenis riser sleeve terdiri dari exothermic sleeve, insulator sleeve atau kombinasi keduanya. Penggunaan jenis exothermic sleeve selain mengatasi penyusutan baja juga meningkatkan feeding efficiency 2 - 3 kali lipat dari sand riser dan meningkatkan kapasitas produksi baja $[4,5]$. Saat ini pengecoran baja di Indonesia menggunakan exothermic sleeve impor dengan bentuk dan ukuran yang terbatas.

Karakteristik dan kinerja exothermic sleeve sangat ditentukan oleh sifat modulus extension factor, nilai kalor dan aliran panasnya [3]. Idamayanti et al. [6] telah memanfaatkan limbah sekam padi sebagai material utama exothermic sleeve. Apalagi sumber limbah sekam padi tersedia dalam jumlah yang sangat besar di Indonesia. Pada tahun 2015 dihasilkan padi 75,3 juta ton [7], dengan estimasi dihasilkan limbah sekam padi 15 juta ton.

Sekam padi berpotensi digunakan sebagai material utama pada exothermic sleeve karena memiliki nilai kalor lebih tinggi yaitu $5,2 \mathrm{MJ} / \mathrm{kg}$ dibandingkan convesional riser $0,422 \mathrm{MJ} / \mathrm{kg}$ dan exothermic sleeve komersial 11,3 MJ/kg [6]. Sekam padi juga dapat diaplikasikan sebagai top riser dan teroksidasi secara lambat dengan menghasilkan kalor yang tinggi [8]. Jenskin et al [9] meneliti limbah sekam padi sebagai bahan biomassa karena memiliki nilai kalor 15,84 MJ/kg dengan sumber karbon $47,53 \%$ dan residu oksida 62\%. Hasil pembakaran sekam padi menghasilkan residu silika amorf dengan porositas yang tinggi [10] sehingga dapat memberikan efek insulasi. Keuntungan lainnya adalah sekam padi mudah dibentuk sebagai briket dengan kadar pengikat yang rendah [10], merupakan senyawa anti-piping, mudah teroksidasi secara lambat [8], dan termasuk eco- 
product dengan emisi yang rendah [11]. Serangkaian penelitian menunjukan potensi sekam padi untuk dimanfaatkan sebagai material utama exothermic-sleeve dengan jumlah yang berlimpah [6]. Sebagai exothermic sleeve, sekam padi telah diuji kinerjanya pada pengecoran baja paduan tinggi GX60Cr15 menghasilkan penahanan temperatur pembekuan baja sampai 511 detik dibandingkan sand riser 273 detik [6]. Modulus Extention Factor (MEF) yang dihasilkan adalah 1.69 sehingga mengklasifikasikan sleeve sekam padi sebagai exothermic sleeve menurut Indian standard IS 15865 : 2009.

Penelitian Idamayanti et al. [6] hanya memberikan informasi kualitatif mengenai karakteristik dasar dari exothermic sleeve sekam padi, sehingga perlu dilakukan penelitian mengenai pengaruh ukuran partikel sekam padi terhadap karakteristik exothermic sleeve sekam padi. Ukuran partikel mempunyai pengaruh signifikan pada pelepasan panas dalam material berpori seperti yang diteliti oleh Nazari et al. [12] dengan penelitian yang analog yaitu pada briket sekam padi. Ukuran partikel sekam padi mempengaruhi nilai kalor, kadar abu dan waktu pembakaran awal dalam briket [12]. Informasi karekteristik ini sangat penting untuk aplikasi exothermic sleeve berbahan dasar sekam padi, karena kinerjanya ditentukan dari kalor yang dilepas, sifat insulasi dan mekanisme pelepasan panas pada material berpori sehingga dapat menahan suhu solidifikasi baja. Hasil penelitian ini tentunya memberikan banyak peluang dan manfaat, diantaranya, dapat mensubstitusi sleeve impor dan meningkatkan nilai tambah limbah sekam padi.

\section{Metodologi}

\section{A Proses Pemisahan Ukuran Sekam Padi}

Sumber sekam padi berasal dari penggilingan padi di kota subang. Sekam padi disaring dengan alat sieve shaker berukuran 40 mesh dan 60 mesh. Pemilihan ukuran ini mengikuti standar ukuran pasir cetak yaitu sekitar 40 - 60 mesh dan riser sleeve akan diintegrasikan pada cetakan pasir saat proses pengecoran baja. Ukuran partikel akan mempengaruhi kemudahan dibentuk dan permeabilitas sleeve. Ukuran partikel yang lebih besar dari 40 mesh relatif sulit dibentuk menjadi sleeve dan mudah retak. Sedangkan jika lebih halus dari 60 mesh maka sleeve mempunyai permeabilitas yang rendah. Permeabilitas meru- pakan faktor penting dalam cetakan pasir untuk melepaskan gas dari cairan baja.

\section{B. Penentuan Komposisi Sleeve Sekam Padi}

Komposisi material pada sleeve sekam padi mempengaruhi kekuatan tekan dan sifat termalnya. Merujuk pada penelitian Idamayanti et al. [6], peningkatan kandungan bahan pengikat akan menurunkan modulus extension factor dari sleeve tetapi meningkatkan kekuatan tekannya. Pada penelitian ini, digunakan variasi pengikat berbahan dasar selulosa asetat $10 \% 11 \%, 12 \%, 13 \%, 14 \%$, dan $15 \%$ terhadap berat total sekam padi. Ukuran partikel sekam padi yang digunakan adalah 40 mesh dan 60 mesh. Persentase bahan pengikat yang akan digunakan untuk membuat sleeve adalah persentase pengikat sekecil mungkin namun memenuhi kekuatan tekan minimum $5 \mathrm{~kg} / \mathrm{cm}^{2}$ sesuai dari spesifikasi exothermic sleeve Indian Standard (IS) 15865 : 2009 untuk mempertahankan sifat termal exothermic sleeve [13].

\section{C. Pembuatan Sleeve Sekam Padi}

Sleeve sekam padi dibuat dua jenis, yaitu berukuran partikel 60 mesh dan 40 mesh. Dengan persentase bahan pengikat yang sebelumnya sudah ditentukan pada subbagian 2.B, sleeve sekam padi dicampur secara homogen dengan bahan pengikat dan dibentuk silinder dengan metoda ramming dan hand pressing pada cetakan logam. Selanjunya sleeve dikeringkan pada suhu $120^{\circ} \mathrm{C}$ selama 2 jam. Ukuran dan bentuk sleeve dapat dilihat pada Gambar 1.
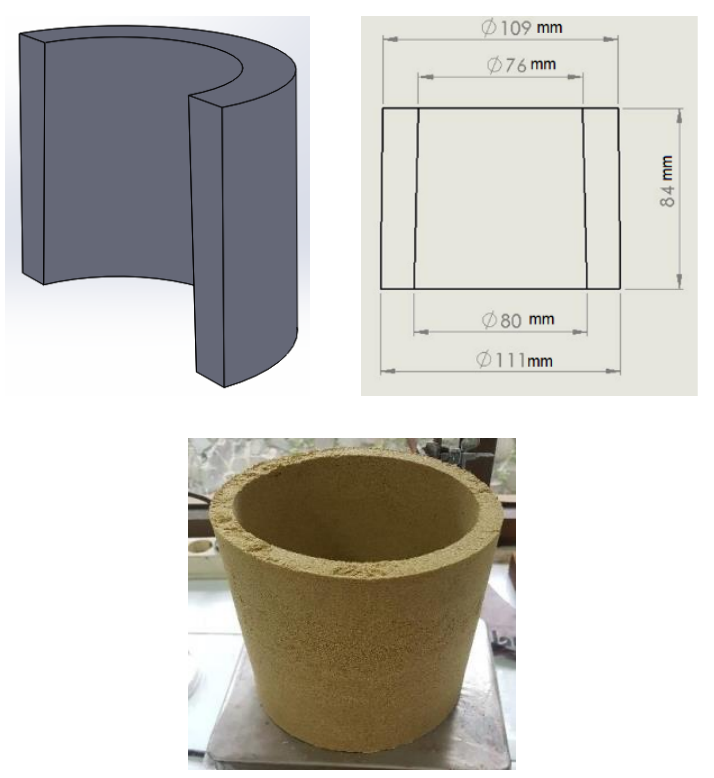

Gambar 1. Dimensi sleeve sekam padi dengan tipe H-sleeve 


\section{D. Pengujian Sleeve Sekam Padi \\ 2.D.1 Pengujian Kekuatan Tekan}
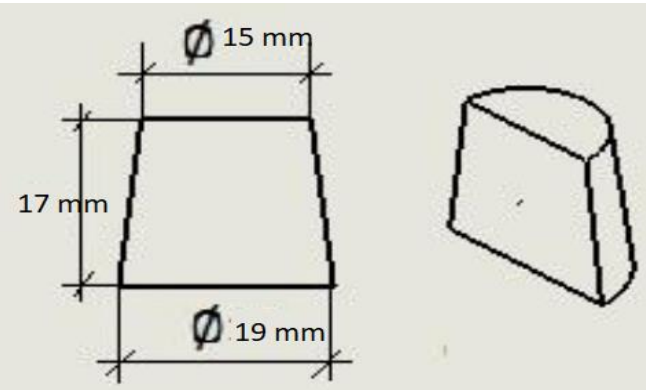

Gambar 3. Dimensi sampel uji untuk pengujian kekuatan tekan.

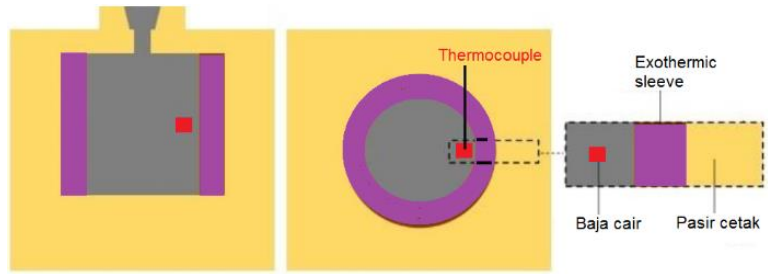

Gambar 2. Layout cetakan dan pengecoran baja

Pengujian kekuatan tekan dilakukan dengan menggunakan alat portable compression tester. Sampel uji dibuat dari sekam padi dicampur bahan pengikat hasil subbagian 2.B dan dicetak pada cetakan keramik dengan dimensi seperti yang ditunjukkan pada Gambar 2, lalu dikeringkan pada suhu $120^{\circ} \mathrm{C}$ selama 2 jam. Sebanyak 5 buah sampel uji untuk setiap persentase bahan pengikat ditekan sampai retak dan kekuatan tekan dihitung berdasarkan pembagian gaya tertinggi dibagi luas permukaan melintang dari sampel uji. Sampel berukuran 40 mesh maupun 60 mesh diuji dengan metode yang sama.

\section{D.2 Pengujian Bulk Density dan Porositas}

Bulk density ditentukan melalui penimbangan sleeve sekam padi dengan ukuran seperti Gambar 1, kemudian dibagi volume sleeve. Volume sleeve dihitung dengan simulasi solidwork 2017 dan diperoleh volume $235,9 \mathrm{~cm}^{3}$. Porositas sleeve dihitung dengan mengolah gambar sleeve dari scanning electron microscope (SEM) dengan software image-J.

\section{D.3 Pengukuran Laju Solidifikasi Baja}

Material coran yang diobservasi adalah baja karbon rendah GS30Mn5 [14] yang mempunyai penyusutan $3 \%$. Untuk mengatasi penyusutan baja, umumnya pengecoran baja karbon rendah memerlukan riser sleeve karena rentang waktu pembekuannya pendek.

Sleeve sekam padi ditempatkan pada cetakan pasir dan proses pengecoran dilakukan dengan layout yang telihat pada Gambar 3. Pada antarmuka cairan logam dan sleeve, dipasang termokopel tipe $\mathrm{R}$ yang tersambung dengan data logger. Selanjutnya, waktu solidifikasi baja dimonitoring sejak penuangan sampai temperatur $1000^{\circ} \mathrm{C}$.

Kemudian, solidifikasi baja ditentukan dari kurva temperatur baja terhadap satuan waktu (detik). Sleeve sekam padi dikarakterisasi sifat termalnya melalui laju solidifikasi baja dan

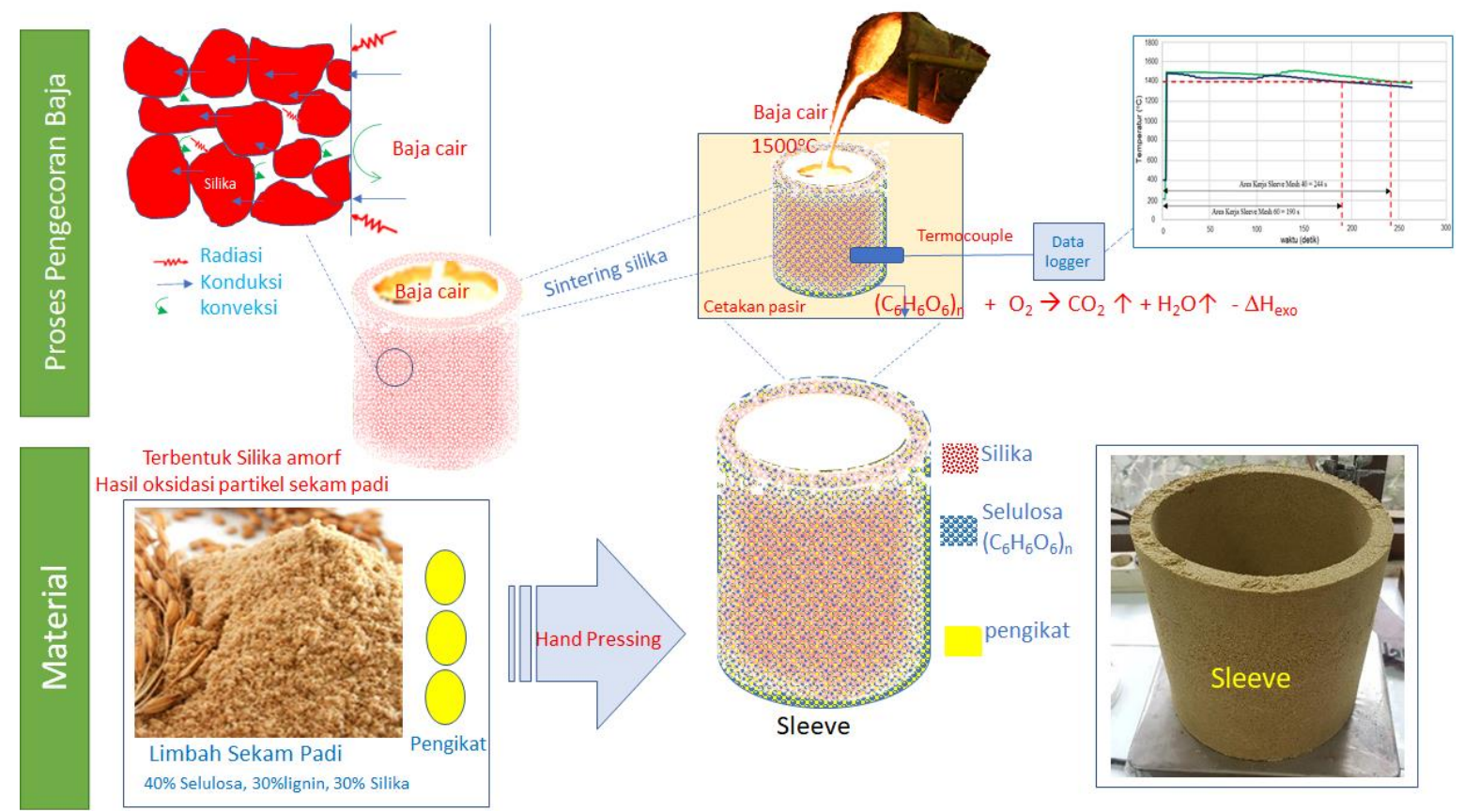

Gambar 4. Ilustrasi proses pembuatan sleeve dari limbah sekam padi sampai penggunaan sleeve pada pengecoran baja. 
perhitungan modulus extension factor (MEF) untuk mengklasifikasikan apakah sleeve sekam padi termasuk exothermic sleeve. Temperatur solidifikasi baja juga diukur terhadap sand riser dengan dimensi yang sama seperti sleeve.

Perbandingan modulus sand riser terhadap sleeve disebut dengan modulus extension factor (MEF) yang dihitung dengan

$$
\mathrm{MEF}=\frac{M_{\text {sand riser }}}{M_{\text {sleeve }}},
$$

dengan $\mathrm{M}$ adalah modulus.

Beberapa nilai modulus sand riser disimulasikan dengan solidCast mengacu pada kurva laju solidifkasi baja.

\section{Hasil dan Pembahasan}

\section{A. Pengaruh ukuran partikel terhadap karakteristik fisik sleeve sekam padi}

Sifat fisik yang umum dikendalikan pada sleeve adalah bulk density, kekuatan tekan dan laju solidifikasi baja. Bulk density mempunyai korelasi dengan porositas [12] saat terkena panas baja cair. Nazari et al [12] meneliti hubungan antara bulk density dengan porositas dari briket sekam padi. Semakin kecil bulk density sleeve akan menghasilkan porositas yang semakin banyak. Maka, dapat diprediksi bahwa sleeve dari partikel sekam padi berukuran 40 mesh dengan bulk density yang lebih rendah $\left(0,56 \mathrm{~kg} / \mathrm{m}^{3}\right)$ akan menghasilkan porositas yang lebih besar daripada sleeve sekam padi dari partikel berukuran 60 mesh (bulk density 0,6 $\left.\mathrm{kg} / \mathrm{m}^{3}\right)$.

Hal ini diperkuat dengan porositas yang terlihat dari citra SEM yang diolah dengan image-J pada Gambar 5 dan Gambar 6. Adanya korelasi antara bulk density dengan porositas juga diperkuat pada laju pembekuan baja seperti pada Gambar 10. Sebagaimana yang dapat dilihat, sleeve dengan ukuran partikel 40 mesh mampu menahan penurunan temperatur solidifikasi baja lebih lama dari sleeve berukuran partikel 60 mesh.

Kekuatan tekan mempengaruhi kestabilan bentuk sleeve selama digunakan sebagai riser sleeve dan kestabilan selama penyimpanan. IS 15865 : 2009 menetapkan minimum kekuatan tekan sebuah sleeve adalah $5 \mathrm{~kg} / \mathrm{cm}^{2}$. Kekuatan tekan sangat ditentukan oleh jumlah bahan pengikat. Semakin tinggi bahan pengikat, semakin tinggi pula kekuatan tekan, seperti yang dapat dilihat pada Gambar 9. Namun demikian, terdapat sifat yang kontradiktif, yaitu besarnya kandungan bahan

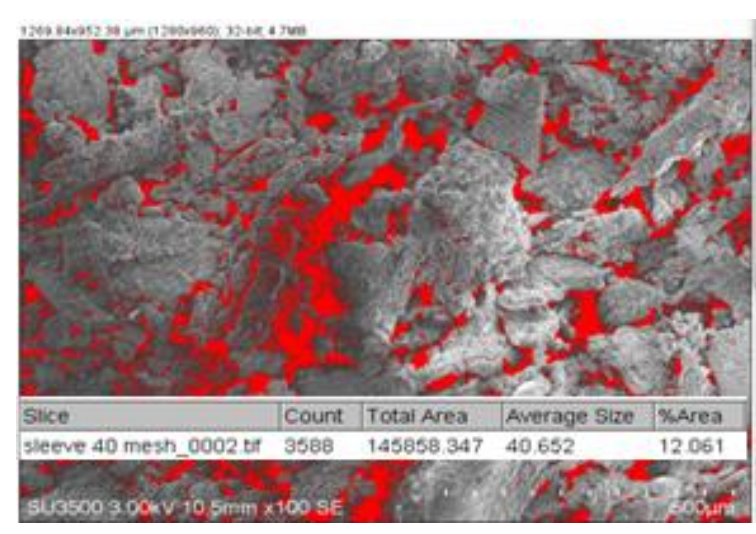

Gambar 5. Citra SEM dan \% porositas sleeve dengan ukuran 40 mesh.

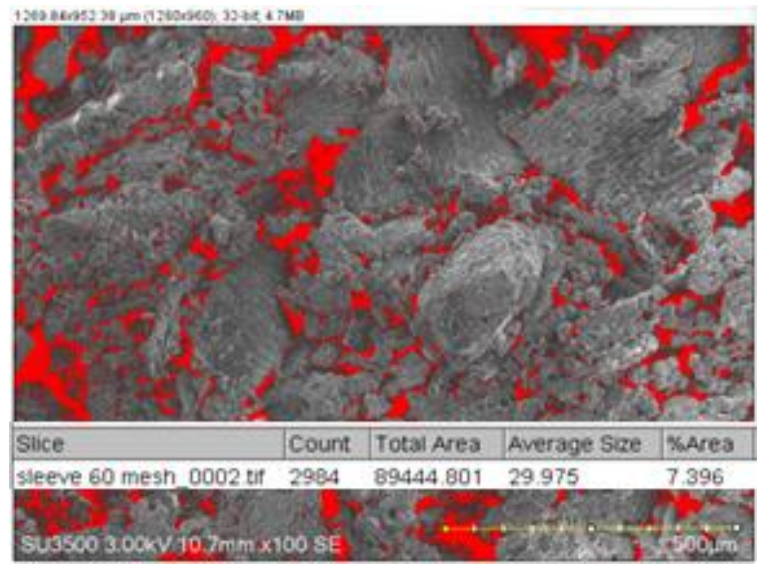

Gambar 6. Citra SEM dan \% porositas sleeve dengan ukuran 60 mesh.

pengikat menurunkan kemampuan sleeve sekam padi dalam menahan laju solidifikasi baja [6]. Hal ini diakibatkan oleh menurunnya jumlah sekam padi sebagai sumber material eksotermik, sekaligus menurunnya jumlah silika amorf yang memberikan efek insulasi. Dengan mempertimbangkan sifat tersebut, maka dipilih bahan pengikat $11 \%$. Sifat mekaniknya sudah memenuhi kekuatan tekan minimum menurut IS 15865 : 2009 . Untuk sleeve dengan ukuran 60 mesh dan 40 mesh dihasilkan kekuatan tekan berturut-turut $6,0 \mathrm{~kg} / \mathrm{cm}^{2}$ dan 6,7 $\mathrm{kg} / \mathrm{cm}^{2}$. Pada berbagai persentase bahan pengikat, sleeve berukuran 60 mesh mempunyai kekuatan tekan yang lebih rendah dari 40 mesh (Gambar 9). Hasil ini sangat dipengaruhi oleh luas permukaan partikel. Untuk menghasilkan kekuatan tekan yang sama, sekam padi berukuran 60 mesh membutuhkan bahan pengikat yang lebih banyak dari ukuran 40 mesh karena luas permukaannya lebih besar. Ukuran partikel pun berpengaruh terhadap jumlah porositas pada sleeve. Sleeve dengan ukuran partikel 40 mesh memiliki porositas $12 \%$ dan 60 mesh memiliki porositas $7 \%$ berdasarkan simulasi dengan software image-J 


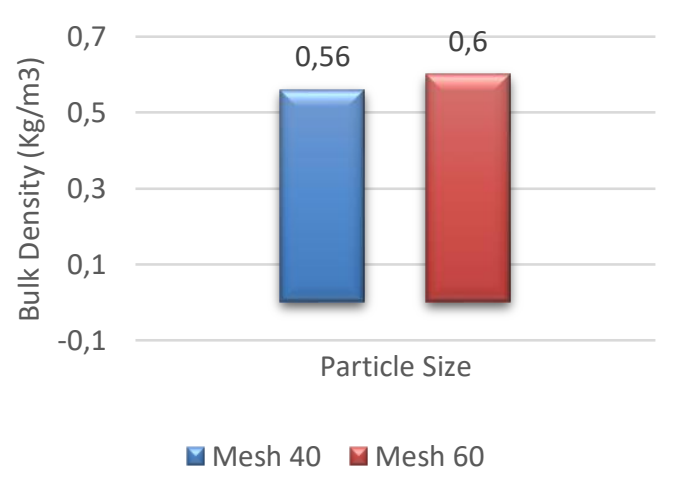

Gambar 8. Bulk density sleeve sekam padi dengan ukuran partikel 40 mesh dan 60 mesh.

Mekanisme pengikatan partikel pada sleeve sekam padi dapat melalui gaya Van der Waals, mechanical interlocking, pengerasan bahan pengikat maupun gaya elektrostatik [15] seperti yang terlihat pada Gambar 8. Pengikatan partikel seperti sekam padi umumnya sama dengan mekanisme pengikatan bahan biomasa untuk pembuatan briket.

\section{B. Pengaruh ukuran partikel sleeve terhadap laju solidifikasi baja}

Laju solidifikasi baja ditentukan dari waktu penuangan cairan baja pada sleeve atau sand riser sampai temperatur solidus baja. Rentang waktu ini juga dikenal sebagai area kerja dari exothermic sleeve maupun sand riser [16]. Penentuan temperatur solidus dihitung berdasarkan carbon equivalent (CE) [17] [persamaan (2)], kemudian diplotkan ke dalam diagram fasa $\mathrm{Fe}-\mathrm{Fe}_{3} \mathrm{C}$.

$$
C E=C+\frac{s i}{38}+\frac{M n}{6}+\frac{N i}{12}+\frac{C r}{1,8}+\frac{M o}{2,3}+\frac{C u}{9,1}
$$

Dari hasil pengujian optical emission spectrometer diperoleh komposisi baja seperti yang terlihat pada Tabel 1. Sehingga diperoleh nilai $\mathrm{CE}=$ 0,69 . Pada nilai $\mathrm{CE}$ ini, diperoleh temperatur solidus $1400^{\circ} \mathrm{C}$ dan temperatur liquidus $1490^{\circ} \mathrm{C}$.

Tabel 1. Komposisi baja karbon rendah GS30Mn5

\begin{tabular}{|c|c|c|c|c|c|c|c|}
\hline & $\mathrm{C}$ & $\mathrm{Si}$ & $\mathrm{Mn}$ & $\mathrm{Ni}$ & $\mathrm{Cr}$ & $\mathrm{Mo}$ & $\mathrm{Cu}$ \\
\hline$\%$ & 0,38 & 0,26 & 1,31 & 0,03 & 0,12 & 0,01 & 0,029 \\
\hline
\end{tabular}

Salah satu parameter kinerja exothermic sleeve adalah kemampuannya menahan temperatur solidifikasi baja melalui pelepasan kalor saat reaksi eksotermik dan oksida hasil reaksi yang bersifat insulator [8]. Hasil pengukuran laju solidifikasi baja pada sleeve sekam padi berukuran 40 mesh, 60 mesh dan sand riser sebagai pembanding, dapat dilihat pada Gambar 10. Pada kondisi awal, baja cair dituangkan pada $1500^{\circ} \mathrm{C}$ dan terjadi penyerapan

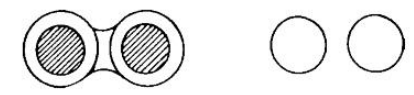

Hardening binders Molecular forces Highly viscous binders (Ven der Waal's forces ) Adsorption layers

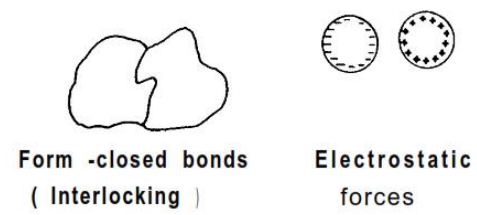

Gambar 7. Mekanisme pengikatan partikel [15].

panas oleh cetakan pasir dan sleeve sekam padi. Setelah kontak dengan baja cair, terlihat bahwa sand riser hanya mampu menahan penurunan temperatur solidifikasi selama 19 detik. Sleeve sekam padi berukuran partikel 60 mesh mempertahankan temperatur liquidus baja selama 190 detik dan ukuran partikel 40 mesh selama 242 detik. Berdasarkan hasil tersebut, ukuran partikel sangat mempengaruhi kemampuan sleeve dalam menahan penurunan temperatur solidifikasi baja. Partikel dengan ukuran 40 mesh memiliki area kerja sleeve yang lebih panjang dari sleeve ukuran 60 mesh, diduga berkaitan dengan tersedianya porositas (12\%) yang cukup memadai sebagai insulator setelah pembakaran sekam padi dan meninggalkan residu silika amorf. Sintering silika amorf pada temperatur tersebut akan menghubungkan riser cavity dan menjadi insulator dengan konduktivitas termal yang rendah [3]. Nazari et al [12] mengkorelasikan ukuran partikel sekam padi terhadap porositas yang terbentuk setelah oksidasi sekam padi, semakin besar ukuran partikel maka porositas abu silika yang dihasilkan semakin besar pula. Ilustrasi terbentuknya silika amorf dan porous dapat dilihat pada Gambar 4. Penelitian yang serupa juga dilakukan oleh Ahn dan

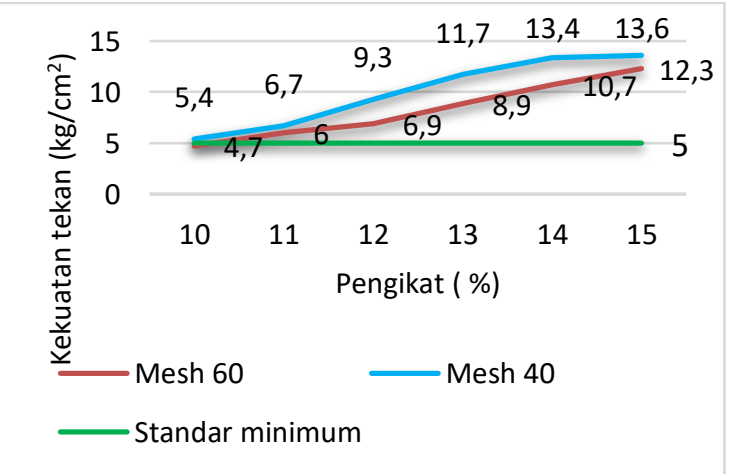

Gambar 9. Pengaruh jumlah bahan pengikat terhadap kekuatan tekan dari sleeve. 


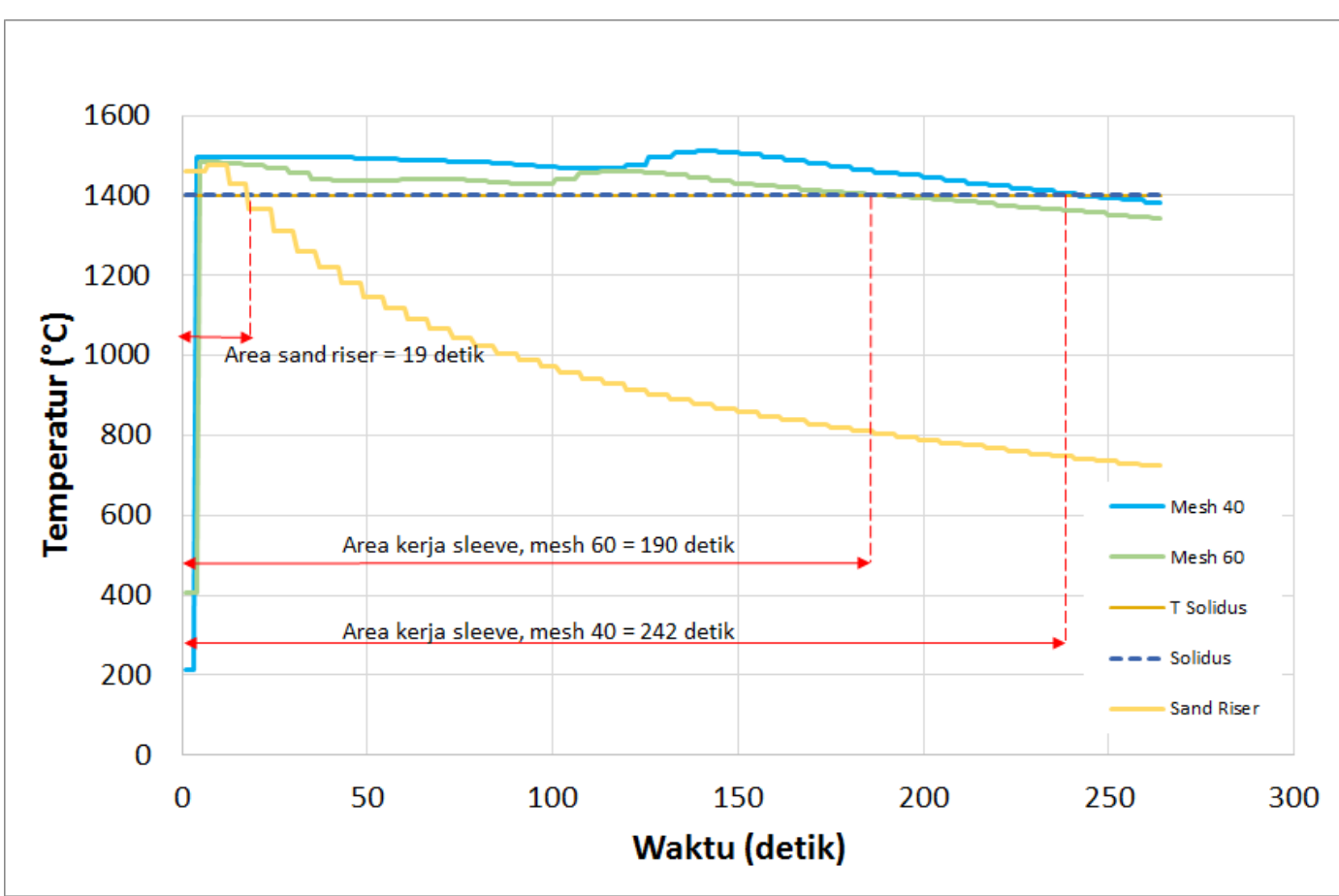

Gambar 10. Pengaruh ukuran partikel sekam padi terhadappenahan temperatur solidifikasi baja.

Jang [18] bahwa peningkatan porositas akan menurunkan konduktivitas termalnya. Dapat disimpulkan bahwa, ukuran partikel 40 mesh dapat menahan waktu solidifikasi baja lebih panjang disebabkan oleh banyaknya porositas dan peran dari silika amorf memberikan efek insulasi.

Jika diamati pada Gambar 10, baik sleeve berukuran 40 mesh maupun 60 mesh memiliki sensitifitas yang sama. Sensitifitas ditunjukkan oleh waktu awal sleeve terbakar saat kontak dengan baja cair. Dalam exothermic sleeve, sensitifitas menjadi faktor yang penting dan menentukan tingkat kualitas exothermic sleeve [3].

\section{C. Modulus Extension Factor (MEF) Sleeve Sekam Padi}

MEF merupakan parameter untuk menentukan klasifikasi dari sebuah sleeve apakah sebagai exothermic sleeve, insulator sleeve atau exothermic-insulating sleeve [13]. Dalam aplikasinya, nilai ini akan mempengaruhi jumlah cairan baja yang disuplai ke dalam cetakan. Semakin tinggi nilai MEF, ukuran sleeve semakin kecil, dan meningkatkan efisiensi pengecoran baja. Nilai MEF sangat tergantung pada kurva solidifikasi baja dan area kerja dari sleeve. Area kerja sleeve berukuran 40 mesh dan 60 mesh adalah 242 detik dan 190 detik. Data ini selanjutnya disimulasikan dengan solidCast seperti yang terlihat pada Tabel 2 .

Tabel 2 adalah ukuran berbagai modulus sand riser, digunakan untuk menentukan modulus sand
Tabel 2. Hasil simulasi modul sand riser terhadap CFS menggunakan software solidCast

\begin{tabular}{|c|c|c|c|c|}
\hline \multirow{2}{*}{ No } & Diameter & \multirow{2}{*}{$\begin{array}{c}\text { Modulus } \\
(\mathrm{mm})\end{array}$} & \multicolumn{2}{|c|}{ CFS* } \\
\cline { 4 - 5 } & & menit & detik \\
\hline 1 & 80 & 1.6 & 0.346 & 20.76 \\
\hline 2 & 90 & 1.8 & 0.651 & 39.06 \\
\hline 3 & 100 & 2 & 0.954 & 57.24 \\
\hline 4 & 112 & 2.24 & 1.352 & 81.12 \\
\hline 5 & 120 & 2.4 & 1.451 & 87.06 \\
\hline 6 & 128 & 2.56 & 1.530 & 91.80 \\
\hline 7 & 136 & 2.72 & 2.254 & 135.24 \\
\hline 8 & 144 & 2.80 & 3.320 & 199.20 \\
\hline 9 & 152 & 3.04 & 4.251 & 255.06 \\
\hline 10 & 160 & 3.2 & 5.200 & 312 \\
\hline 11 & 240 & 4.8 & 6.791 & 407.46 \\
\hline 12 & 248 & 4.96 & 7.862 & 471.72 \\
\hline 13 & 150 & 3 & 3.664 & 219.84 \\
\hline 14 & 95 & 1.9 & 0.829 & 49.74 \\
\hline 15 & 134 & 2.68 & 1.955 & 117.30 \\
\hline 16 & 156 & 3.12 & 4.525 & 271.50 \\
\hline 17 & 140 & 2.8 & 3.271 & 196.26 \\
\hline 18 & 244 & 4.88 & 7.184 & 431.04 \\
\hline
\end{tabular}

*Critical fraction solid

riser yang sebanding dengan waktu solidifikasi baja saat menggunakan sleeve sekam padi. Diperoleh sleeve sekam berukuran partikel 60 mesh setara dengan modulus sand riser 2,80 sedangkan 
POSITRON Vol. 10, No. 1 (2020), Hal. 27 - 33

Tabel 3. Perhitungan modulus extension factor (MEF)

\begin{tabular}{|c|c|c|c|c|c|c|}
\hline No & Mesh & $\begin{array}{c}\text { Diameter } \\
\text { Sleeve }\end{array}$ & $\begin{array}{c}\text { Modulus } \\
\text { Sleeve }\end{array}$ & $\begin{array}{c}\text { Diameter } \\
\text { Sand Riser }\end{array}$ & $\begin{array}{c}\text { Modulus } \\
\text { Sand Riser }\end{array}$ & MEF $=\frac{M_{\text {Sand riser }}}{M_{\text {sleeve }}}$ \\
\hline 1 & 60 & 80 & 1.6 & 140 & 2.80 & 1.75 \\
\hline 2 & 40 & 80 & 1.6 & 152 & 3.04 & 1.9 \\
\hline
\end{tabular}

berukuran partikel 40 mesh setara dengan modulus sand riser 3,04

Melalui persamaan (2) diperoleh sleeve sekam berukuran partikel 60 mesh menghasilkan MEF 1,75 sedangkan 40 mesh menghasilkan MEF 1,9 seperti yang terlihat pada Tabel 3. Keduanya memenuhi kriteria sebagai exothermic sleeve menurut IS 15865:2009 yaitu minimum 1,6.

\section{Kesimpulan}

Karakteristik sleeve sekam padi sebagai exothermic sleeve dapat dipengaruhi oleh ukuran partikelnya. Dengan jumlah bahan pengikat yang sama, kekuatan tekan sleeve sekam berukuran 40 mesh lebih tinggi dari 60 mesh. Ukuran partikel juga berpengaruh terhadap kinerjanya sebagai riser sleeve pada pengecoran baja karbon rendah. Sleeve berkuran partikel 40 mesh mampu menahan laju pembekuan baja 52 detik lebih lama dibanding mesh 60 sehingga berpengaruh juga terhadap nilai modulus extension factor berturut-turut 1,90 dan 1,75 .

\section{Ucapan Terima Kasih}

Penulis mengucapkan terima kasih kepada Polman Bandung. Penelitian ini didanai oleh Polman Bandung melalui Hibah PTUKK.

\section{Daftar Pustaka}

[1] Plutshack, L.A., Suschil, A.L., and Foseco, I. Riser Design. ASM Handbook, Volume 15 Casting. , 369-384. (2010).

[2] Brown, J. ,Feeding of Castings,ButterworthHeinemann, 2000.

[3] Francis, J.L. and Pardoe, P.G.A. The Feeding of Iron Casting. Applied Science in the Casting of Metals, (1970).

[4] Lipowska, B., Witek, J., and Stec, K., Aluminium dross-based insulating and exothermic materials for metallurgical industry10(4), pp.115-118, 2010.

[5] Williams, T. J., Hardin, R. A., and Beckermann, C., Characterization of the Thermophysical Properties of Riser Sleeve Materials and Analysis of Riser Sleeve Performance, Proceedings of the 69th SFSA Technical and Operating Conference, 5.9pp.1-28, 2015.
[6] Idamayanti, D., Purwadi, W. , Bandanadjaja, B., and Triadji, R., Rice Husk Waste as an Exothermic Material for a Riser Sleeve for Steel Casting, International Journal of Technology, 11(1), pp.71-80, 2020.

[7] Badan Pusat Statistik Produksi Padi Menurut Provinsi (ton), 1993-2015. (2015).

[8] Rao, P. N. ,Manufacturing Technology,McGraw Hill Education India, 2013.

[9] Jenkins, B. M., Baxter, L. L., Miles, T. R., and Miles, T. R., Combustion properties of biomass, Fuel Processing Technology, 54(1-3), pp.1746, 1998.

[10] Maiti, S., Dey, S., Purakayastha, S., and Ghosh, B., Physical and Thermochemical Characterization of Rice Husk Char As A Potential Biomass Energy Source, Bioresource Technology, 97(16), pp.2065-2070, 2006.

[11] Unrean, P., Lai Fui, B. C., Rianawati, E., and Acda, M., Comparative Techno-Economic Assessment and Environmental Impacts of Rice Husk-to-Fuel Conversion Technologies, Energy, 151pp.581-593, 2018.

[12] Nazari, M. M., San, C. P., and Atan, N. A., Combustion Performance of Biomass Composite Briquette from Rice Husk and Banana Residue, International Journal on Advanced Science Engineering Information Technology, pp.455-460, 2019.

[13] The Foundry and Steel Castings Sectional Committee, Exothermic and Insulating Sleeves for Use in Foundries, Bureau of Indian Standard IS 15865, 2009.

[14] ASTM ,Handbook of Comparative world steel standards,ASTM International, 2004.

[15] Grover, P.D. and Mishra, S.K. Biomass Briquetting: Technology and Practices. FAO Regional Regional Wood Energy Development Programme in Asia, Bangkok, Thailand. , (46) . (1996).

[16] Wlodawer, R. ,Directional Solidification of Steel Castings,Pergamon Press, 1966.

[17] Kasuya, T. and Hashiba, Y. Carbon equivalent to assess hardenability of steel and prediction of HAZ hardness distribution. Nippon Steel Technical Report. , (95) . (2007).

[18] Ahn, J. and Jung, J., Effects of Fine Particles on Thermal Conductivity of Mixed Silica Sands, Applied Sciences, 7(7), 2017. 